\title{
Microstructural Evolution of Rapid Solidified Al-Ni Alloys
}

\author{
Manuel Alejandro Martínez-Villalobos, ${ }^{1}$ Ignacio Alejandro Figueroa, ${ }^{1 *}$ Miguel Angel Suarez, ${ }^{1}$ \\ Gabriel Ángel Lara Rodríguez, ${ }^{1}$ Omar Novelo Peralta, ${ }_{1}^{1}$ Gonzalo González Reyes, ${ }^{1}$ Ismeli Alfonso López, ${ }^{2}$ \\ Jorge Verduzco Martínez ${ }^{3}$ and Cesar Díaz Trujillo ${ }^{4}$ \\ 1 Instituto de Investigaciones en Materiales, UNAM. Circuito exterior, Ciudad Universitaria, Coyoacán. 045410, México, D.F. \\ 2 Instituto de Investigaciones en Materiales, Unidad Morelia, Universidad Nacional Autónoma de México, Campus Morelia \\ UNAM, Antigua Carretera a Pátzcuaro No. 8701, Col. Morelia, Michoacán, México \\ 3 Instituto de Investigación en Metalurgia y Materiales, UMSNH. Fco. J. Mújica S/N, Col. Felícitas del Río, Morelia, \\ Michoacán, México, C.P. 58030 \\ 4 Facultad de Ciencias Químicas e Ingeniería, Universidad Autónoma de Baja California, Tijuana, Baja California, México \\ * iafigueroa@unam.mx \\ Telephone: (55) 56224651, Fax (55) 56161371
}

Received March 2 $2^{\text {nd }}, 2016$; Accepted June $1^{\text {st }}, 2016$.

\begin{abstract}
In this study, Al-Ni alloy ribbons in hypoeutectic, euctectic and hypereutectic compositions were obtained by melt spinning. The microstructural changes of the samples, from the as-cast to rapid solidification processes at different $\mathrm{Cu}$ wheel tangential velocities were characterized by X-ray diffraction, scanning electron microscopy and transmission electron microscopy. The rapid solidification caused morphological transformation of the $\mathrm{Al}-\mathrm{Al}_{3} \mathrm{Ni}$ microstructure from acicular in the as-cast condition to globular in the melt spun ribbons and the growth of the metastable $\mathrm{Al}_{9} \mathrm{Ni}_{2}$ intermetallic compound, which acted as reinforcing particles. Due to the increment of the $\mathrm{Ni}$ content and the presence of these intermetallic compounds, with size of $\sim 5 \mathrm{~nm}$, distributed in the aluminum matrix, the hardness of the alloys significantly increased from the hypoeutectic $(90 \mathrm{VHN})$ to the hypereutectic (205VHN) composition.

Key words: aluminum alloys, rapid solidification, intermetallic compounds, reinforcing particles, hardness.
\end{abstract}

\section{Introduction}

Aluminum and its alloys are the most important structural materials for industrial applications due to its good mechanical properties and corrosion resistance combined with low density. As it has been reported, the mechanical properties of pure aluminum can be improved when small amounts of second phases with high elastic modulus (similar to those used in composite materials) are formed by the addition of copper, silicon, nickel and other elements (i.e. $\mathrm{Al}_{2} \mathrm{Cu}, \mathrm{Al}_{3} \mathrm{Ni}, \mathrm{Al}_{3} \mathrm{Ti}_{1}, \mathrm{Al}_{13} \mathrm{Fe}_{4}$ ) [1-8].

The Al-Ni alloys around the eutectic composition can be considered as an in situ particulate-reinforced metal matrix composite $\left(\mathrm{Al}-\mathrm{Al}_{3} \mathrm{Ni}\right)$. The intermetallic compounds in the Al-Ni system have low density, high strength, good oxidation resistance and, in some cases, an enhancement in strength with temperature increment. However, these intermetallics present low ductility at low temperature. [1]
Resumen. En este estudio, cintas de la aleación Al-Ni en las composiciones hipoeutéctica, eutéctica e hipereutéctica fueron obtenidas por la técnica de "melt spinning". Los cambios microestructurales, desde la colada hasta las cintas solidificadas rápidamente a distintas velocidades de solidificación, fueron caracterizados por difracción de Rayos $\mathrm{X}$, microscopía electrónica de barrido y microscopia electrónica de transmisión. La solidificación rápida causó una transformación morfológica de la microestructura $\mathrm{Al}-\mathrm{Al}_{3} \mathrm{Ni}$ acicular en la muestras de colada a una morfología globular en la cintas solidificadas rápidamente y el crecimiento del compuesto intermetálico metaestable $\mathrm{Al}_{9} \mathrm{Ni}_{2}$, el cual actuó como partícula reforzadora. Debido al incremento del contenido de $\mathrm{Ni}$ y la presencia de estos compuestos intermetálicos, con tamaño de $\sim 5 \mathrm{~nm}$, distribuidos en la matriz de aluminio, la dureza de la aleaciones aumentó significativamente de la composición hipoeutéctica $(90 \mathrm{VHN})$ a la hipereutéctica $(205 \mathrm{VHN})$.

Palabras clave: aleaciones de aluminio, solidificación rápida, compuestos intermetálicos, partículas reforzadoras, dureza.

It is well known that the mechanical properties of particulate-reinforced metal matrix composites are widely dependent of the size, the volume fraction of the reinforcements and the nature of the matrix/reinforcement interface [9]. Commonly, the size of the reinforcing particles is in the order of several to tens of micrometers and almost never beneath $1 \mu \mathrm{m}$. A good control of the intermetallic phase particles is necessary to attain alloys with adequate ductility [10]. The presence of nickel aluminides $\left(\mathrm{Al}_{3} \mathrm{Ni}\right)$ particles dispersed in aluminum matrix can increased its strength [11] and enhance the wear resistance [12].

On other hand, in the rapid solidification process (RSP) of metals and alloys, high cooling rates $\left(10^{4}-10^{8} \mathrm{~K} / \mathrm{s}\right)$ are applied during the solidification from liquid state. It is well known that RSP can promote a grain refinement of the microstructure, including the refinement of any possible segregation, as well as the induction of some metastable effects like the extension of 
solid solubility limits and the formation of metastable or glassy phases $[13,14]$.

The Al-Ni alloys in as-cast condition are brittle and inadequate for structural applications, in a previous work [1], it was analyzed the influence of RSP on the microstructure of hypereutectic Al-8 wt.\% Ni alloy and their mechanical properties. The reported microstructure is constituted by globular-like $\mathrm{Al}_{9} \mathrm{Ni}_{2}$ and $\mathrm{Al}_{3} \mathrm{Ni}$ particles distributed into the aluminum matrix. The improvement in Vickers hardness was attributed to the concentration of globular intermetallic $\mathrm{Al}_{9} \mathrm{Ni}_{2}$ particles within the grain boundaries and the increment of the dislocation density caused by high cooling rates. It is likely that the mechanical properties of the Al-Ni alloys with Ni content lower than $8 \mathrm{wt} . \%$ (hypereutectic composition) could also be increased by the presence of globular intermetallic compounds with nanoscale size formed under rapid solidification conditions.

From the above, the aim of this work is to analyze the influence of $\mathrm{Ni}$ content in the Al-Ni alloys at different concentrations (i.e. hypoeutectic, eutectic and hypereutectic compositions) and the rapid solidification on the morphology and distribution of the intermetallic compounds. Finally, the influence of these intermetallics compounds on the Vickers microhardness of such alloys will also be assessed.

\section{Experimental procedures}

Hypoeutectic, eutectic and hypereutectic Al-Ni alloys were obtained melting $\mathrm{Al}(99.9 \%$ purity) and $\mathrm{Ni}(99.9 \%$ purity) into graphite crucible using Leybold-Heraeus induction furnace under Ar atmosphere to prevent the oxidation. Table 1 shows the composition of the studied alloys.

Table 1. Chemical composition of the Al-Ni alloys studied.

\begin{tabular}{lcc}
\hline Composition & $\mathrm{Al}($ wt. \%) & $\mathrm{Ni}($ wt.\%) \\
\hline Hypoeutectic & 95.9 & 4.1 \\
Eutectic & 93.9 & 6.1 \\
Hypereutectic & 91.9 & 8.1 \\
\hline
\end{tabular}

The molten alloy was poured into an iron mold inside the furnace chamber to produce ingots of $200 \mathrm{~g}$. Then, square sections of $10 \mathrm{~g}$ were cut in order to produce ribbon samples. These were cast at different wheel speeds by melt spinning in order to vary the ribbon thickness and cooling rates (i.e. 20, 30 and $40 \mathrm{~m} / \mathrm{s}$ ). A controlled atmosphere of He with an injection pressure of $0.4 \mathrm{bar}(40 \mathrm{kPa})$ and a nozzle orifice diameter of $0.8 \mathrm{~mm}$ were used. The gap distance between the crucible (fused silica) nozzle and the copper wheel was approximately $5 \mathrm{~mm}$. Microstructural characterization of as-cast ingots and spun ribbons was carried out using field emission scanning electron microscope Jeol JSM-7600F equipped with low angle backscatter electron detector. These observations were supported with $\mathrm{X}$-ray diffraction (XRD) analysis, using a Bruker AXS model
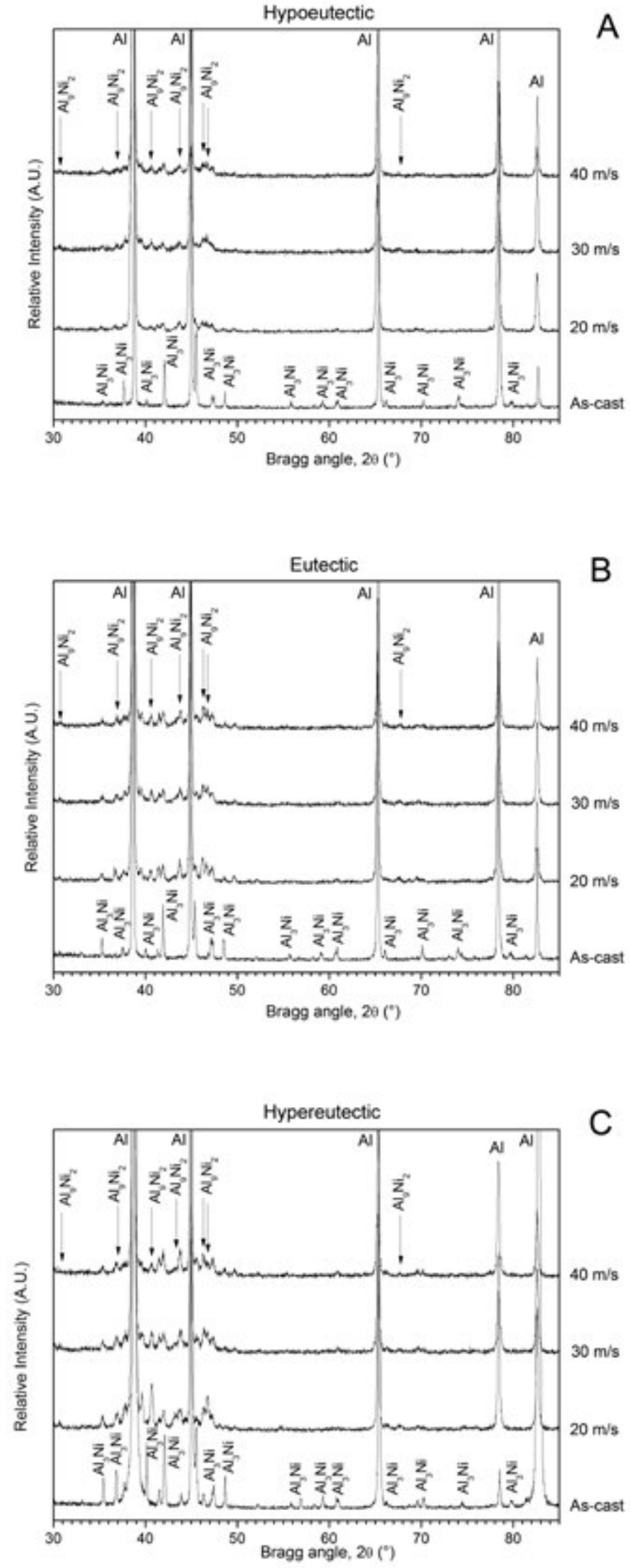

Fig. 1. XRD patterns of the A) hypoeutectic, B) eutectic and C) hypereutectic Al-Ni alloys in the as-cast condition and the melt-spun ribbons at different wheel speeds. 
D8 Advanced diffractometer, with $\mathrm{Cu} \mathrm{K} \alpha$ radiation and a graphite monochromator, operated at $35 \mathrm{kV}$. Transmission electron microscopy (TEM) was performed to identify the intermetallic compounds distributed in the aluminum matrix, using a Jeol JEM-1200EX equipment. The microhardness behavior were analyzed using Vickers hardness tester Shimadzu HMV-G21 FA with a load of $10 \mathrm{~g}$ for $15 \mathrm{~s}$, this conditions were set, since in melt spun ribbons (due to the thickness) the hardness is very sensitive to the load applied.

\section{Results and discussion}

\section{Microstructural characterization}

Fig. 1A-C shows the XRD patterns of the hypoeutectic, eutectic and hypereutectic Al-Ni alloys in the as-cast condition and the melt-spun ribbons performed at different wheel speeds. The XRD pattern of the hypoeutectic alloy in the as-cast condition (Fig. 1A) is constituted only by peaks corresponding to the $\alpha$-Al and $\mathrm{Al}_{3} \mathrm{Ni}$ phases. On the other hand, the XRD patterns of the melt-spun ribbons are constituted by the same $\alpha-\mathrm{Al}$ and $\mathrm{Al}_{3} \mathrm{Ni}$ phases and by the peak corresponding to the metastable $\mathrm{Al}_{9} \mathrm{Ni}_{2}$ phase. From this figure, for the melt-spun ribbons, the peaks corresponding to stable $\mathrm{Al}_{3} \mathrm{Ni}$ phase decreased and the peaks belonging to the metastable $\mathrm{Al}_{9} \mathrm{Ni}_{2}$ augmented as the wheel speed increased.

A similar behavior is observed in the eutectic and hypereutectic compositions (Fig. 1B and 1C, respectively), where the XRD patterns for the as-cast condition, showed only the peaks related to the $\alpha-\mathrm{Al}$ and $\mathrm{Al}_{3} \mathrm{Ni}$ phases. In the same sense, for the melt-spun ribbons, the intensity of the peaks of $\mathrm{Al}_{3} \mathrm{Ni}$ dropped and the peaks of intermetallic metastable $\mathrm{Al}_{9} \mathrm{Ni}_{2}$ phase tended to increase as the wheel speed and the amount of $\mathrm{Ni}$ content increased. It is worth noting that the amount of the metastable $\mathrm{Al}_{9} \mathrm{Ni}_{2}$ phase is somehow proportional to $\mathrm{Ni}$ content in the alloys. As mentioned above, this can be clearly observed in the XRD patterns, where the intensity of the peaks corresponding to this phase not only increased by the wheel speed but also by the amount of $\mathrm{Ni}$ in the investigated binary alloy.
Fig. 2A-C shows the as-cast microstructures of the hypoeutectic, eutectic and hypereutectic Al-Ni alloys. Fig. 2A shows the microstructure of the hypoeutectic alloy, here a typical microstructure composed by $\alpha$-Al rich zones surrounded by the eutectic phase is observed. As can be seen in fig. 2B, the microstructure of the eutectic alloy is completely composed by small needles of $\mathrm{Al}_{3} \mathrm{Ni}$ intermetallic compound surrounded by $\alpha$-Al matrix. Finally, for the hypereutectic composition, the microstructure (fig. 2C) is constituted by coarse $\mathrm{Al}_{3} \mathrm{Ni}$ intermetallic compound surrounded by the eutectic phase.

Fig. 3A-I shows the microstructures of the Al-Ni alloys solidified at high cooling rates. Figs. 3A, B and $\mathrm{C}$ show the microstructures of the hypoeutectic alloy solidified by means of the melt spinning process at 20,30 and $40 \mathrm{~m} / \mathrm{s}$, respectively. The obtained melt-spun ribbons showed that the $\mathrm{Al}_{3} \mathrm{Ni}$ needles in the eutectic broke down to form a highly homogeneous globular morphology. It is also observed that globular intermetallic compounds are distributed inside the grains formed during the solidification. Figs. 3D, E and F, show the microstructure of the eutectic alloy solidified at 20,30 and $40 \mathrm{~m} / \mathrm{s}$, respectively. In these micrographs, it can be seen that the needle-like morphology of the eutectic was totally transformed to globular shape.

The hypereutectic Al-Ni alloy solidified at the higher cooling rate (wheel speed of $40 \mathrm{~m} / \mathrm{s}$ ) showed the finest and well-distributed globular compounds (figs. 3G, H and I). The coarse $\mathrm{Al}_{3} \mathrm{Ni}$ intermetallic compound observed in the as-cast alloy was not observed. In fig. 3I, a close up of the area indicated is shown. As can be observed, rather small globular intermetallic compounds are still present inside the grains.

From the micrographs, the Ni content had a significant effect in the grain size, as when the Ni content increased the grain size significantly decreased. In addition, as it is shown in the circle area in fig. 3, when the wheel speed increased the grain size decreased, leading to a reduction in the sizes of the intermetallic compounds.

Fig. 4 shows the TEM micrograph of the hypoeutectic composition solidified at wheel speed of $20 \mathrm{~m} / \mathrm{s}$. As can be observed, it is possible to identify some crystalline aggregates with size of $5 \mathrm{~nm}$ approximately. The selected area electron

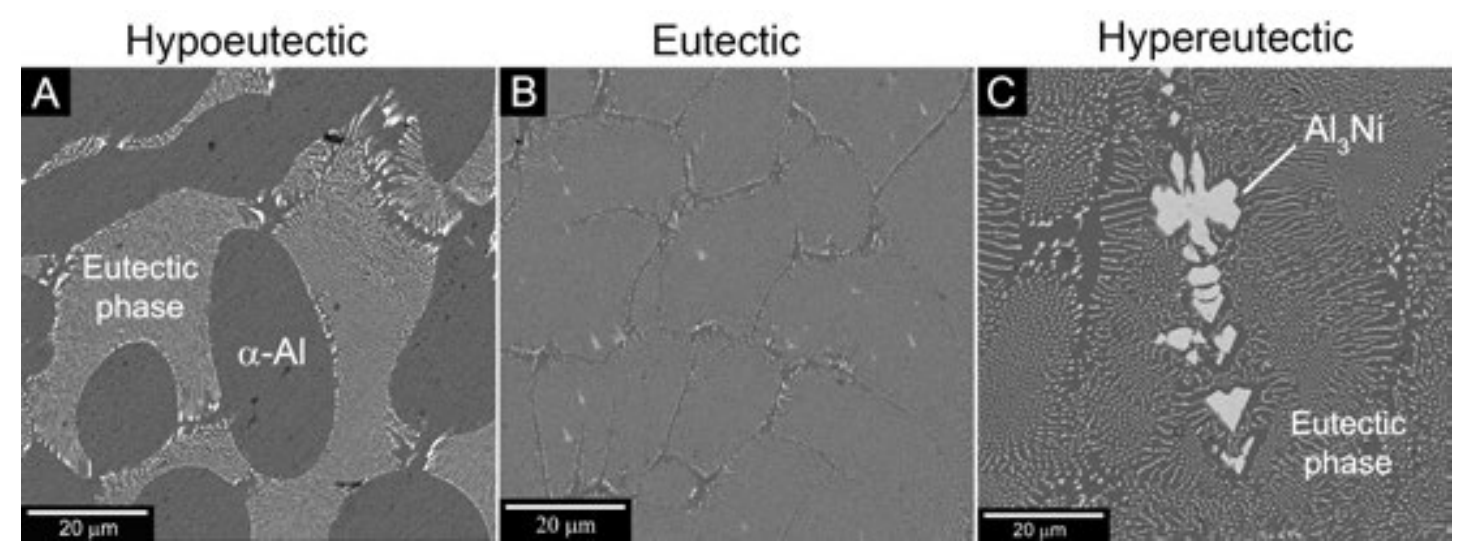

Fig. 2. SEM micrographs of the A) hypoeutectic, B) eutectic and C) hypereutectic Al-Ni alloys in as-cast condition. 


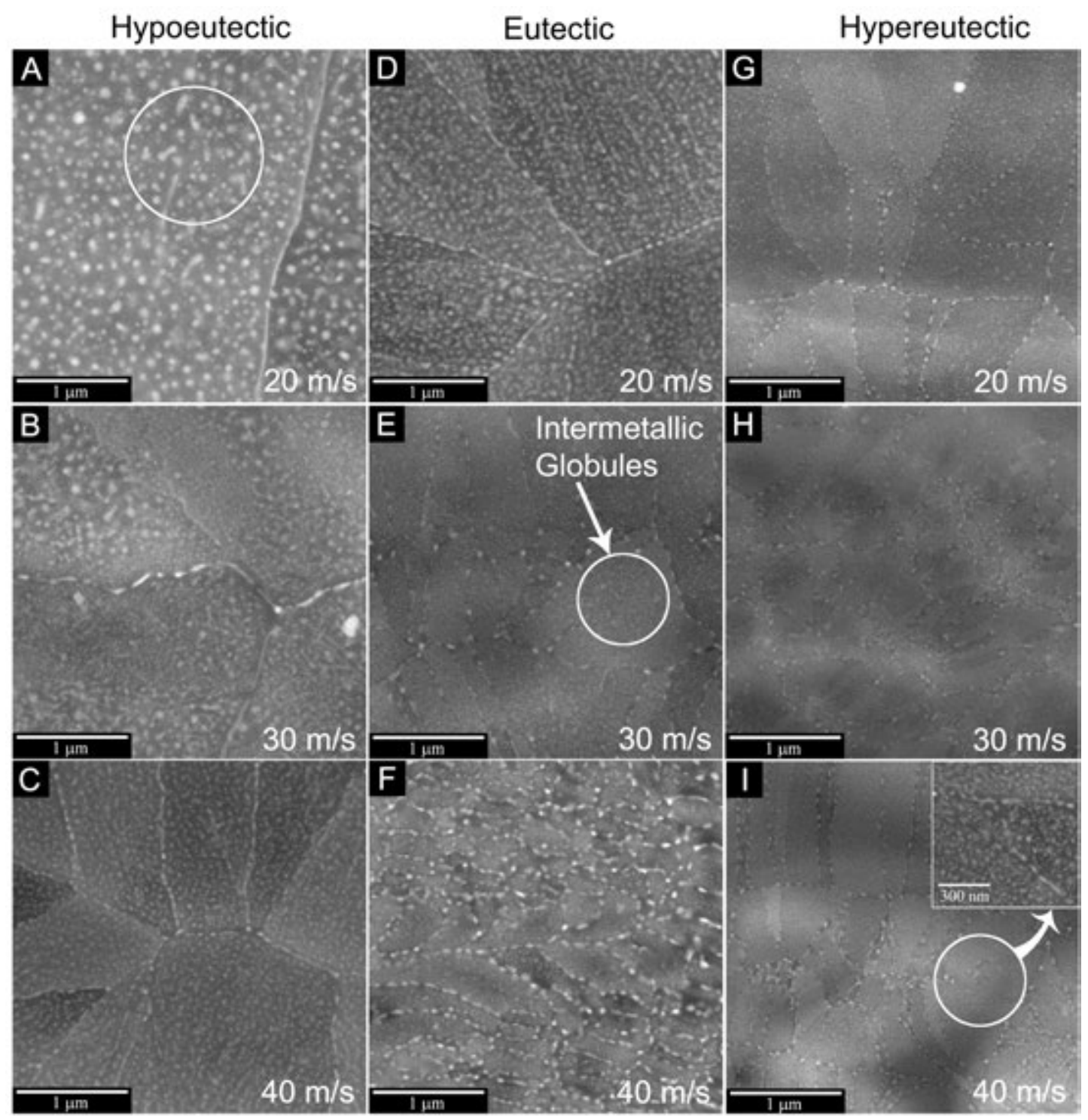

Fig. 3. SEM micrographs of the melt-spun ribbons solidified at different tangential wheel speed velocities (20, 30 and 40m/s, respectively): (A-C) hypoeutectic, (D-F) eutectic and (G-I) hypereutectic alloys.

diffraction pattern (SAED) showed a ring shape-pattern, which is characteristic of nanocrystalline materials. The table 2 shows the theoretical and the experimental interplanar distance of these rings. According to the SAED pattern the presence of the metastable $\mathrm{Al}_{9} \mathrm{Ni}_{2}$ and stable $\mathrm{Al}_{3} \mathrm{Ni}$ phases is confirmed.

During the rapid solidification, the solid solution becomes supersaturated with $\mathrm{Ni}$ and the $\mathrm{Ni}$ begins to redistribute forming Ni-rich and Al-rich regions. Depending on the initial average composition, the redistribution of $\mathrm{Ni}$ can favor the formation of either $\mathrm{Al}_{9} \mathrm{Ni}_{2}$ or $\mathrm{Al}_{3} \mathrm{Ni}$. The reaction of $\mathrm{Al}$ and $\mathrm{Ni}$ could follow the sequence [15]:

$$
\mathrm{Al}+\mathrm{Ni} \rightarrow \mathrm{Al}_{9} \mathrm{Ni}_{2}+\mathrm{Ni} \rightarrow \mathrm{Al}_{3} \mathrm{Ni}+\mathrm{Ni} \rightarrow \mathrm{Al}_{3} \mathrm{Ni}_{2}
$$

In a previous study [1], it was found that the increment in the Ni concentration during the rapid solidification increased
Table 2. Indexation of SAED pattern of hypoeutectic melt-spun ribbon at a wheel speed of $20 \mathrm{~m} / \mathrm{s}$.

\begin{tabular}{cccc}
\hline $\begin{array}{c}\text { Theoretical } \\
\text { interplanar } \\
\text { distance } \\
\left(\mathrm{d}_{\mathrm{hk}}\right)[\AA]\end{array}$ & $\begin{array}{c}\text { Experimental } \\
\text { interplanar } \\
\text { distance } \\
\left(\mathrm{d}_{\mathrm{hk}}\right)[\AA]\end{array}$ & $\begin{array}{c}\text { Identified } \\
\text { phase }\end{array}$ & $\begin{array}{c}\text { Planes } \\
\text { (hkl) }\end{array}$ \\
\hline 2.1041 & 2.1122 & $\mathrm{Al}_{9} \mathrm{Ni}_{2}$ & $(320)$ \\
1.7603 & 1.7980 & $\mathrm{Al}_{3} \mathrm{Ni}$ & $(321)$ \\
1.2498 & 1.2499 & $\mathrm{Al}_{9} \mathrm{Ni}_{2}$ & $(\overline{4} 33)$ \\
1.0740 & 1.0743 & $\mathrm{Al}_{3} \mathrm{Ni}$ & $(601)$ \\
\hline
\end{tabular}

the free $\mathrm{Ni}$ in the liquid, promoting the thermodynamic conditions to form the intermetallic $\mathrm{Al}_{9} \mathrm{Ni}_{2}$ compound. Additionally, the saturation level was reached in less time than the originally considered, as a consequence, at higher Ni concentration the 

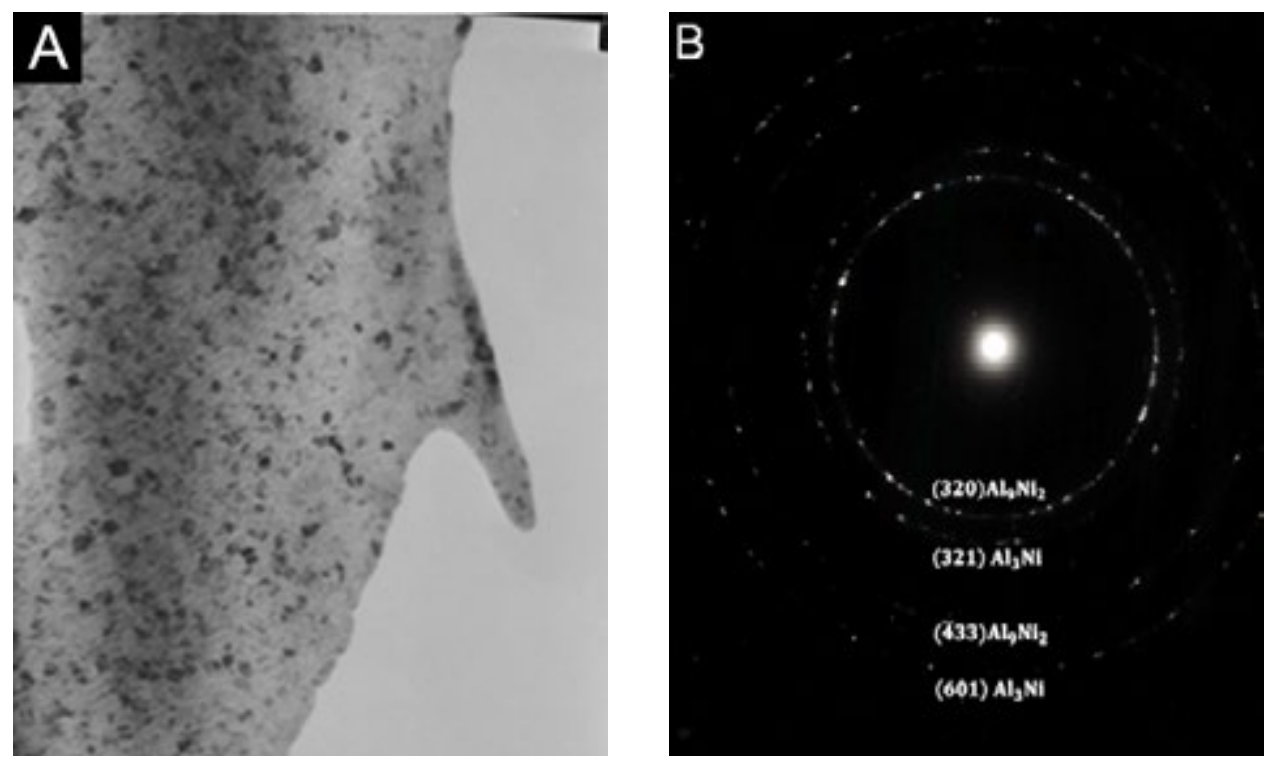

Fig. 4. A) TEM image showing the presence of globular intermetalic compounds embedded in a $\alpha$-Al rich matrix, B) electron diffraction pattern of the crystalline aggregates.

$\mathrm{Al}_{9} \mathrm{Ni}_{2}$ phase nucleated mainly inside the grains and when increasing the solidification rate the intermetallic compound becomes finer and homogenously distributed. Therefore, the globular intermetallic compounds observed inside the grains of the rapid solidified Al-Ni alloys (Fig. 3) could correspond to the $\mathrm{Al}_{9} \mathrm{Ni}_{2}$ phase, as was previously detected by XRD.

\section{Vickers microhardness}

The behavior of the Vickers microhardness as a function of solidification rate (speed wheel) for the studied compositions is shown in fig. 5. For the Al-Ni alloys in the as-cast condition, a small increment in the hardness as a function of $\mathrm{Ni}$ content was observed from the hypoeutectic to hypereutectic composition. As the solidification rate increased, the Vickers hardness augmented following a linear behavior. The highest hardness corresponded to the alloys solidified at a speed wheel of $40 \mathrm{~m} / \mathrm{s}$ reaching values of up to 90,170 and $205 \mathrm{VHN}$ for the hypoeutectic, eutectic and hypereutectic compositions, respectively. In the case of the hypereutectic alloy solidified at speed wheel of $40 \mathrm{~m} / \mathrm{s}$, the results showed an increment of $160 \%$, i.e. 205 $\mathrm{VHN}$, with respect to as-cast condition (79 VHN). This improvement can be attributed to the grain size refinement, distribution and morphology of the metastable $\mathrm{Al}_{9} \mathrm{Ni}_{2}$ intermetallic compound.

\section{Conclusions}

Rapid solidification by melt spinning caused a morphological transformation of the $\mathrm{Al}-\mathrm{Al}_{3} \mathrm{Ni}$ eutectic from acicular to globular in the studied Al-Ni alloys. Under the rapid solidification condition, the growth of the intermetallic $\mathrm{Al}_{9} \mathrm{Ni}_{2}$ compound inside the grains was favored. This phase played an important

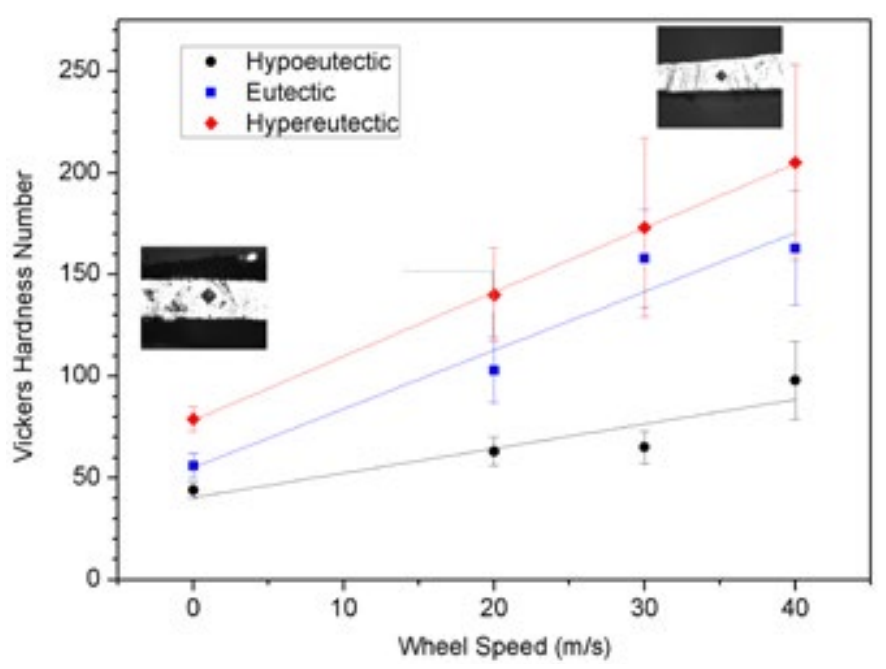

Fig. 5. Vickers microhardness behavior of the hypoeutectic, eutectic and hypereutectic Al-Ni alloys as function of solidification rate (wheel speed).

role as reinforcing particles. Due to the increment of $\mathrm{Ni}$ content and the homogenously distributed (within the aluminum matrix) intermetallic compounds ( $\sim 5 \mathrm{~nm}$ diameter), the hardness of the alloys significantly increased from the hypoeutectic (90 VHN) to hypereutectic $(205 \mathrm{VHN})$ composition. Although the highest hardness was achieved for the hypereutectic alloy, the increment in hardness in the hypoeutectic and eutectic alloys may be more useful.

\section{Acknowledgements}

The authors are grateful for the financial support of CONACyT through grant No. 178289 and DGAPA-PAPIIT-UNAM 
No. IN101016/27. Gonzalo Gonzalez thanks the financial support of DGAPA-PAPIIT-UNAM No. IN110014. Adriana Tejeda, E. Hernández, F. García, A. López-Vivas, C. Flores Morales and J. Romero are also acknowledged for their valuable technical assistance. "Por mi raza hablará el espíritu".

\section{References}

1. Gonzalez, G.; Lara-Rodríguez, G.A.; Sandoval-Jiménez, A.; Saikaly, W.; Charai, A. Mater. Characterization 2008, 59, 1607- 1612.

2. Chemingui, M.; Khitouni, M.; Jozwiak, K.; Mesmacque, G.; Kolsi, A. Mater. Des. 2010, 31, 3114-3139.

3. Kucukomeroglu, T. Mater. Des. 2010, 31, 782-789.

4. Bayoumi, M.A.; Negm, M.I.; El-Gohry, A.M. Mater. Des. 2009, 30, 4469-4477.

5. Taghavi, F.; Saghafian, H.; Kharazi, Y.H.K. Mater. Des. 2009, 30, 1604-1611.
6. Osório, Wislei R.; Peixoto Leandro, C.; Moutinho, Daniel J.; Gomes, Laércio G.; Ferreira, Ivaldo L.; Garcia, Amauri. Mater. Des. 2011, 32, 3832-3837.

7. Nikseresht, Z.; Karimzadeh, F.; Golozar, M.A.; Heidarbeigy, M. Mater. Des. 2010, 31, 2643-2648.

8. Suarez, M.A.; Figueroa, I.; Cruz, A.; Hernandez, A.; Chavez, J.F. Mater Res, 2012, 5, 1-7.

9. Tjong, S.C.; Ma, Z.Y. Mater. Sci. Eng. R. 2000, 29, 49-113.

10. Kumar, K.S. Int Mater Rev. 1990, 35-6, 293-327.

11. Uan, J.Y.; Chen, L.H.; Lui, T.S. Acta mater. 2001, 49, 313-320.

12. Da Costa, C.E.; Zapata, W.C.; Velazco, F.; Ruiz Prieto, J.M.; Torralba, J.M. J. Mater. Process. Technol. 1999, 92-93, 66-70.

13. Zhang, Z.; Bian, X.; Wang, Y.; Liu, X.; Wang, Y. J. Alloys Comp. 2002, 339, 180-188.

14. Zhang, Z.; Bian, X.; Wang, Y.; Liu, X.; Wang, Y. J. Alloys Comp. 2003, 349, 121-128.

15. Blobaum, K.J.; Van Heerden, D.; Gavens, A.J.; Weihs, T.P. Acta Mater. 2003, 51, 3871-3884. 